Doi: 10.47650/pjphsr.v1i2.269

ISSN (Online): 2777-1296

OJS: http://journal.unpacti.ac.id/index.php/pjphsr

\title{
DIET BEHAVIOR DURING COVID-19 PERIOD THE ENFORCEMENT OF COMMUNITY ACTIVITY RESTRICTIONS
}

\section{Perilaku Diet selama Covid-19 di Masa Pemberlakuan Pembatasan Kegiatan Masyarakat}

\author{
Anto J. Hadi ${ }^{1}$, Erni Yetti $\mathbf{R}^{2}$, Haslinah Ahmad ${ }^{1}$, Nur Hamdani Nur ${ }^{3}$, Adi Antoni ${ }^{4}$ \\ ${ }^{1}$ Departemen Kesehatan Masyarakat, Fakultas Kesehatan, Universitas Aufa Royhan, Padangsidimpuan, Indonesia \\ ${ }^{2}$ Departemen Promosi Kesehatan dan Ilmu Perilaku, Akademi Kebidanan Sinar Kasih Toraja, Tana Toraja, Indonesia \\ ${ }^{3}$ Departemen Kesehatan Lingkungan, Fakultas Kesehatan Masyarakat, Universitas Pancasakti, Makassar, Indonesia \\ ${ }^{4}$ Departemen Keperawatan, Fakultas Kesehatan, Universitas Aufa Royhan, Padangsidimpuan, Indonesia
}

*Alamat Korespondensi: antoarunraja@gmail.com

\begin{tabular}{l}
\hline Article Info \\
\hline Article History \\
Received: 16 Agustus 2021 \\
Revised : 23 Agustus 2021 \\
Accepted : 26 Agustus 2021
\end{tabular}

\section{Keywords :}

Covid-19, diet

behavior, PPKM

\begin{tabular}{|c|}
\hline ABSTRACT / A \\
\hline $\begin{array}{l}\text { The impact of Corona Virus Disease } 2019 \text { (Covid-19) has affected the lifestyles of all } \\
\text { people in the world, especially the food consumption patterns of various age groups. } \\
\text { However, in the protracted Covid-19 pandemic, the implementation of restrictions on } \\
\text { community activities (PPKM) was implemented which resulted in changes in certain } \\
\text { dietary behavior to overcome covid-19. This study aims to analyze dietary behavior } \\
\text { during covid-19 during PPKM. This type of research is an analytic survey with a cross } \\
\text { sectional design. Respondents aged } 18 \text { years and over as the population and samples } \\
\text { taken by accidental sampling were } 493 \text { participants. Data were collected using research } \\
\text { questionnaires and data analysis by independent t-test or ANOVA analysis. The results } \\
\text { obtained that most of the participants self-reported that they had recently reduced } \\
\text { eating out and the proportion of people who chose to use supplements to prevent covid- } \\
19 \text { had increased substantially during PPKM by } 275 \text { (55,8\%), less than half of the } \\
\text { participants took recommended dietary behaviors, including individual food portions } \\
\text { and participants who followed these behaviors had better dietary diversity. In } \\
\text { conclusion, during the PPKM period, participants still followed certain dietary behaviors } \\
\text { to overcome covid-19. While some dietary behaviors are adopted to help prevent } \\
\text { transmission, such as avoiding eating together and taking multivitamins. }\end{array}$ \\
\hline $\begin{array}{l}\text { Dampak Corona Virus Disease } 2019 \text { (Covid-19) telah mempengaruhi gaya hidup seluruh } \\
\text { masyarakat dunia terutama pola konsumsi makanan berbagai kelompok umur. Namun } \\
\text { dalam berlarut-larut pandemi covid-19 ini sehingga diterapkan Pemberlakuan } \\
\text { Pembatasan Kegiatan Masyarakat (PPKM) yang berakibat pada perubahan perilaku diet } \\
\text { tertentu untuk mengatasi covid-19. Studi ini bertujuan untuk menganalisis perilaku diet } \\
\text { selama covid-19 di masa PPKM. Jenis Penelitian ini adalah survey analitik desain cross } \\
\text { sectional study. Responden usia } 18 \text { tahun keatas sebagai populasi dan sampel dengan } \\
\text { pengambilan sampel secara accidental sampling sebanyak } 493 \text { peserta. Data } \\
\text { dikumpulkan dengan menggunakan kuesioner serta teknik analisis data dengan uji-t } \\
\text { independen atau analisis ANOVA. Hasil diperoleh sebagian besar peserta melaporkan } \\
\text { sendiri bahwa mereka baru-baru ini mengurangi makan di luar serta proporsi orang } \\
\text { yang memilih untuk menggunakan suplemen untuk mencegah covid-19 telah } \\
\text { meningkat secara substansial selama PPKM sebanyak } 275 \text { (55,8\%), kurang dari } \\
\text { setengah peserta mengikuti perilaku diet yang direkomendasikan, termasuk porsi } \\
\text { makanan individu serta peserta yang mengikuti perilaku ini memiliki keragaman } \\
\text { makanan yang lebih baik. Kesimpulannya, selama periode PPKM peserta masih } \\
\text { mengikuti perilaku diet tertentu untuk mengatasi covid-19. Sementara beberapa } \\
\text { perilaku diet diadopsi untuk membantu mencegah penularan seperti menghindari } \\
\text { makan bersama serta mengonsumsi multivitamin. }\end{array}$ \\
\hline
\end{tabular}




\section{PENDAHULUAN}

Pandemi Corona Virus Disease 2019 (Covid19) telah mengganggu banyak aspek kehidupan sehari-hari dan menjadi masalah kesehatan masyarakat global serta memberikan tantangan besar bagi gaya hidup masyarakat. Sejak ditetapkan sebagai pandemi global oleh Organisasi Kesehatan Dunia (WHO), Covid-19 memberikan tantangan besar pada sistem kesehatan, ekonomi, dan pasokan makanan secara global, dan memiliki pengaruh besar pada gaya hidup individu (Nicola et al., 2020). Penduduk Indonesia yang tinggal di dalam dan di luar negeri telah diminta untuk tinggal di rumah untuk mengasingkan diri sejak pemberlakuan pembatasan kegiatan masyarakat (Thorik, 2020). Namun, adanya mutasi epidemi Covid-19 domestik kadang-kadang terjadi di beberapa tempat, seperti Jawa, Bali dan Sulawesi. Di tengah wabah Covid-19 yang berkepanjangan, perilaku tertentu tetap dianjurkan kepada warga untuk mencegah infeksi dan menjaga kesehatan, seperti menjaga jarak sosial, memakai masker, dan mengikuti aturan perilaku diet (Zhao et al., 2020).

Beberapa orang memilih untuk makan lebih banyak makanan ringan dan makanan berkalori tinggi lainnya untuk mengatasi depresi dan kecemasan yang dipicu oleh pandemi (Zhang, Zhao, et al., 2020), dan beberapa dimaksudkan untuk mencegah virus SARS-Cov-2 melalui minum alkohol dan cuka (Scarmozzino and Visioli, 2020). Cara membeli makanan juga diubah dengan pembatasan kegiatan di luar dan transportasi (Sidor and Rzymski, 2020). Perubahan perilaku diet ini sedikit banyak mempengaruhi kesehatan masyarakat. Meskipun menurut data dari survei tahap pertama, keragaman makanan secara umum baik (Khubchandani, Kandiah and Saiki, 2020), perilaku diet yang tidak tepat masih dapat menimbulkan beberapa masalah gizi. Salahsatu studi sebelumnya melaporkan bahwa peningkatan asupan makanan berkalori tinggi berkontribusi pada kehamilan yang signifikan penambahan berat badan pada wanita (Zhang, Zhang, et al., 2020). Iran melaporkan setidaknya ada 2.197 orang keracunan dan 244 kematian akibat untuk minum alkohol beracun (minuman berbasis metanol) yang diyakini dapat mencegah Covid-19 (Malekian, 2020). Pada masa Pemberlakuan Pembatasan Kegiatan Masyarakat (PPKM), Survei gizi tahap pertama pada warga Kota Padangsidimpuan telah dilakukan. Berdasarkan data dari tahap pertama survei dan studi yang dilakukan di luar selama pandemi tersebut, ditemukan bahwa perilaku diet sangat dipengaruhi oleh situasi masa pandemik Covid-19. Saat ini, orang-orang secara bertahap telah kembali ke pekerjaan normal dan kehidupan sehari-hari. Hal tersebut mempengaruhi perilaku diet orang Indonesia apakah masih dipengaruhi oleh situasi pandemik Covid-19. Selain itu, untuk mencegah terjadinya infeksi covid-19, perilaku diet tertentu juga didorong oleh kebiasaan makan secara individu. Penelitian ini bertujuan untuk mengetahui perubahan perilaku diet masyarakat selama covid-19 di masa PPKM.

\section{BAHAN DAN METODE}

Desain penelitian ini menggunakan cross sectional study yang di lakukan pada bulan Juli sampai Agustus 2021 di Kota Padangsidimpuan. Populasi dan sampel adalah responden usia 18 tahun keatas dengan pengambilan sampel secara accidental sampling di fasilitas umum Kota Padangsidimpuan sebanyak 493 peserta. Data dikumpulkan dengan menggunakan kuesioner penelitian, pengolahan data dengan komputer serta Data dianalisis menggunakan SPSS. Data disajikan sebagai nilaia mean \pm standard deviation (SD) atau persentase. Perbandingan Household Dietary Diversity Score (HDDS) untuk responden dengan karakteristik yang berbeda diuji dengan uji-t independen atau analisis ANOVA.

\section{HASIL}

Tabel 1 merupakan hasil perbandingan karakteristik sosio-demografis responden dengan hasil bahwa responden relatif muda, tinggal di perkotaan dan tingkat pendidikan yang lebih 
rendah (sekolah menengah atas atau bawah) dan lebih tinggi pendidikan diploma dan S1. Skor Keragaman Diet Rumah Tangga (HDDS) rata-rata adalah 9,2 $\pm 1,9$. Selama periode PPKM, orang- orang dengan keluarga yang lebih tinggi pendapatan menunjukkan HDDS yang lebih tinggi secara signifikan. Karakteristik sosio-demografis lainnya tidak terkait dengan HDDS.

Tabel 1. Skor Keragaman Diet Rumah Tangga (HDDS) Responden dengan karakteristik Berbeda

\begin{tabular}{|c|c|c|c|c|}
\hline \multicolumn{2}{|c|}{ Karakteristik Responden } & \multirow{2}{*}{$\frac{\mathbf{n}}{66}$} & \multirow{2}{*}{$\begin{array}{c}\text { HDDS (Mean } \pm \text { SD) } \\
9,2 \pm 1,9\end{array}$} & \multirow{3}{*}{$\frac{\mathbf{p}}{0,721}$} \\
\hline Jenis Kelamin & Laki-Laki & & & \\
\hline & Perempuan & 52 & $9,1 \pm 2,0$ & \\
\hline \multirow[t]{2}{*}{ Kelompok Umur } & 18-35 Tahun & 46 & $9,1 \pm 2,0$ & \multirow{2}{*}{0,412} \\
\hline & >35 Tahun & 74 & $9,2 \pm 2,1$ & \\
\hline \multirow[t]{3}{*}{ Pendidikan } & Rendah & 25 & $8,6 \pm 2,1$ & \multirow{3}{*}{0,003} \\
\hline & Menengah & 38 & $9,2 \pm 2,1$ & \\
\hline & Tinggi & 15 & $9,3 \pm 1,8$ & \\
\hline \multirow[t]{2}{*}{ Status Pekerjaan } & Bekerja & 56 & $9,3 \pm 1,9$ & \multirow{2}{*}{0,624} \\
\hline & Tidak Bekerja & 23 & $8,7 \pm 2,1$ & \\
\hline \multirow[t]{2}{*}{ Pendapatan } & Rp. $\leq 2.000 .000,-$ & 43 & $9,2 \pm 21$ & \multirow{2}{*}{0,051} \\
\hline & Rp. >2.000.000,- & 55 & $9,2 \pm 1,9$ & \\
\hline
\end{tabular}

Sumber: Data Primer, 2021

Tabel 2. Perbandingan Skor Keragaman Diet Rumah Tangga (HDDS) Responden dengan Perilaku Diet Berbeda terhadap Covid-19 di Masa PPKM

\begin{tabular}{|c|c|c|c|c|}
\hline \multicolumn{2}{|c|}{ Perilaku Diet dengan Covid 19} & \multirow{2}{*}{$\begin{array}{c}\mathbf{n}(\%) \\
118(23,9)\end{array}$} & \multirow{2}{*}{$\begin{array}{c}\text { HDDS (Mean } \pm \text { SD) } \\
9,1 \pm 1,9\end{array}$} & \multirow{3}{*}{$\begin{array}{c}\mathbf{p} \\
0,005\end{array}$} \\
\hline Asupan Vitamin C & Ya & & & \\
\hline & Tidak & $120(24,2)$ & $9,2 \pm 2,1$ & \\
\hline \multirow[t]{2}{*}{ Asupan Probiotik } & Ya & $78(15,8)$ & $9,2 \pm 1,9$ & \multirow{2}{*}{0,001} \\
\hline & Tidak & $55(11,2)$ & $8,8 \pm 2,2$ & \\
\hline \multirow[t]{2}{*}{ Asupan Produk Kesehatan Lain } & Ya & $79(16,0)$ & $9,1 \pm 2,0$ & \multirow{2}{*}{0,002} \\
\hline & Tidak & $43(8,7)$ & $8,7 \pm 2,1$ & \\
\hline
\end{tabular}

Sumber: Data Primer, 2021

Tabel 2 menunjukkan hasil mengenai perilaku diet yang dilakukan untuk mengatasi Covid-19 di masa PPKM, Sebanyak 275 (55,8\%) peserta yang menggunakan suplemen makanan (vitamin C, probiotik, dan suplemen makanan lainnya) serta makanan dan minuman fungsional untuk mengatasi covid-19, dan sebagian kecil dari peserta yang diteliti masih menggunakan makanan mentah. Peserta yang memilih mengonsumsi vitamin $\mathrm{C}$, probiotik, suplemen makanan lainnya, dan makanan dan minuman fungsional untuk mengatasinya Covid-19 terutama pada responden yang memiliki HDDS yang lebih tinggi secara signifikan.

\section{PEMBAHASAN}

Perilaku diet dapat sangat mempengaruhi asupan makanan, asupan gizi, dan kesehatan masyarakat. Selain itu, penelitian ini juga menunjukkan bahwa orang yang mengikuti perilaku diet yang lebih sehat, termasuk memilih untuk menggunakan suplemen makanan dan makanan fungsional, dan menyiapkan makanan mentah dan dimasak secara terpisah dan sendiri. Ini dapat dijelaskan dengan mengakui bahwa kelompok orang ini lebih peduli tentang kesehatan mereka dan mengikuti gaya hidup yang lebih sehat, termasuk makan makanan yang beragam (Carroll et al., 2020). 
Ketika membandingkan perilaku pada periode pasca pembatasan sosial berskala besar (PSBB) dengan perilaku selama PPKM, ditemukan bahwa tingkat penggunaan suplemen makanan dan makanan dan minuman fungsional untuk mengatasi Covid-19 tidak banyak berubah pada 275 (55,8\%) responden pada sebagian kecil responden ada yang berperilaku diet tidak rasional dan tidak sehat seperti minum alkohol. Makanan layanan pesan online melalui dalam jaringan (daring) adalah jaminan kuat aksesibilitas makanan selama PPKM. Berdasarkan keterbatasan data layanan makanan online di masa pandemi, terdapat beberapa kekhawatiran, seperti yang terjadi di beberapa negara, yaitu layanan makanan online yang disediakan lebih tinggi makanan dengan padat energi, jangkauan layanan online tidak dapat menjangkau daerah pedesaan, kelompok rentan terbatas pada akses teknologi digital, dan potensi masalah keamanan pangan (Gröber and Holick, 2021).

Pendidikan kesehatan masih sangat dibutuhkan dan harus dilanjutkan dalam waktu selama pandemi Covid-19. Perilaku diet mengenai keamanan pangan juga diselidiki. Memasak makanan sepenuhnya dan menyiapkan makanan mentah dan dimasak secara terpisah selalu menjadi pesan utama dalam pendidikan keamanan pangan untuk menghindari penyakit bawaan makanan (Maimaiti et al., 2018).Dalam studi saat ini, sebagian besar responden mengikuti saran untuk memasak makanan sepenuhnya. Namun, 23,4\% responden tidak menyiapkan makanan mentah dan dimasak secara terpisah, yang dapat dengan mudah menyebabkan kontaminasi makanan. Pelajaran yang dipetik dari covid-19, masyarakat saat ini mendorong masyarakat untuk menggunakan sendok makan serta mengadopsi porsi makanan individu (Zhang, Zhang, et al., 2020). Namun, karena perilaku ini sangat berbeda dari adat kebiasaan, bahwa lebih dari separuh peserta tidak mengikuti perilaku kebiasaan baru ini. Untuk meminimalkan risiko infeksi Covid-19, perubahan perilaku pola makan terkait keamanan makanan harus dimasukkan dalam program saat ini pada promosi kesehatan. Dengan perkembangan pandemi global berikutnya, covid-19 telah secara signifikan mengubah gaya hidup dan perilaku orang sementara dan mungkin juga membawa efek permanen. Membandingkan data dengan itu dari tahap pertama survei yang berlangsung selama PPKM, yang kedua saat ini tahap penelitian menunjukkan bahwa orang masih mengikuti perilaku diet tertentu untuk mengatasi covid-19 (de Faria Coelho-Ravagnani et al., 2021).

Sementara itu, perilaku diet baru diperoleh untuk membantu mencegah infeksi. Perilaku ini adalah langsung terkait dengan keragaman makanan pada orang dewasa. WHO secara khusus mengatakan bahwa tidak ada bukti makanan menjadi sumber infeksi selama pandemi, baik melalui makan atau menyentuh makanan yang terkontaminasi (Shi, Xiang and Zhang, 2020). Pada saat yang sama, baru-baru ini wabah Covid-19 ditemukan jejak virus pada paket makanan beku di pasar di beberapa negara, termasuk China. Pada periode tahun 2019 lebih dari setengah responden melaporkan bahwa mereka mengalami penurunan makan di restoran $(61,6 \%)$, konsumsi makanan laut $(53,1 \%)$, mengimpor makanan beku $(57,1 \%)$ dan makanan mentah $(60,5 \%)$. Pada saat yang sama, lebih banyak orang lebih suka memilih memasak sendiri di rumah (64,8\%) (Fisher et al., 2021). Dalam hal ini, di satu sisi yaitu penduduk secara spontan berkurang untuk asupan makanan, frekuensi makan di luar, dan konsumsi makanan dibawa pulang. Perlu juga dicatat bahwa tidak cukup asupan makanan laut pada populasi juga telah diamati pada penelitian sebelumnya yang dilakukan selama pandemi Covid-19 dan selama masa PPKM.

Asupan makanan yang menurun dan memperburuk dapat membawa masalah asupan gizi potensial, terutama bagi mereka yang tinggal di rumah.

\section{KESIMPULAN DAN SARAN}

Perubahan perilaku diet selama PPKM. Masyarakat mengikuti perilaku tertentu untuk 
mencegah penyakit, seperti mengurangi makan di luar, mengosumsi makanan dan minuman produk kesehatan seperti suplemen vitamin $C$ dan menghindari makan bersama. Sementara itu, perilaku ini memiliki dampak tertentu pada keragaman makanan.

Untuk memastikan makanan keragaman, layanan pemesanan dan pengiriman makanan online sangat membantu pada masa PPKM. Edukasi kesehatan perilaku diet masih sangat dibutuhkan selama covid-19, bahkan selama periode PPKM.

\section{DAFTAR PUSTAKA}

Carroll, N. et al. (2020) 'The impact of COVID-19 on health behavior, stress, financial and food security among middle to high income Canadian families with young children', Nutrients. Multidisciplinary Digital Publishing Institute, 12(8), p. 2352.

de Faria Coelho-Ravagnani, C. et al. (2021) 'Dietary recommendations during the COVID-19 pandemic', Nutrition Reviews. Oxford University Press, 79(4), pp. 382-393.

Fisher, D. et al. (2021) 'Seeding of outbreaks of COVID-19 by contaminated fresh and frozen food', BioRxiv. Cold Spring Harbor Laboratory, pp. 2008-2020.

Gröber, U. and Holick, M. F. (2021) 'The coronavirus disease (COVID-19)-A supportive approach with selected micronutrients', International Journal for Vitamin and Nutrition Research. Hogrefe Verlag.

Khubchandani, J., Kandiah, J. and Saiki, D. (2020) 'The COVID-19 pandemic, stress, and eating practices in the United States', European Journal of Investigation in Health, Psychology and Education. Multidisciplinary Digital Publishing Institute, 10(4), pp. 950956.

Maimaiti, M. et al. (2018) 'How we eat determines what we become: opportunities and challenges brought by food delivery industry in a changing world in China', European journal of clinical nutrition.
Nature Publishing Group, 72(9), pp. 12821286.

Malekian, S. (2020) 'Iran Confronts Deadly Alcohol Crisis in Midst of Dealing with Coronavirus', $A B C$ News Network.

Nicola, M. et al. (2020) 'The socio-economic implications of the coronavirus pandemic (COVID-19): A review', International journal of surgery. Elsevier, 78, pp. 185-193.

Scarmozzino, F. and Visioli, F. (2020) 'Covid-19 and the subsequent lockdown modified dietary habits of almost half the population in an Italian sample', Foods. Multidisciplinary Digital Publishing Institute, 9(5), p. 675.

Shi, M. in, Xiang, C. and Zhang, X. (2020) 'Impacts of the COVID-19 pandemic on consumers' food safety knowledge and behavior in China', Journal of Integrative Agriculture. Elsevier, 19(12), pp. 2926-2936.

Sidor, A. and Rzymski, P. (2020) 'Dietary choices and habits during COVID-19 lockdown: experience from Poland', Nutrients. Multidisciplinary Digital Publishing Institute, 12(6), p. 1657.

Thorik, S. H. (2020) 'Efektivitas pembatasan sosial berskala besar di indonesia dalam penanggulangan pandemi covid-19', ADALAH, 4(1).

Zhang, J., Zhao, A., et al. (2020) 'Dietary behaviors in the post-lockdown period and its effects on dietary diversity: the second stage of a nutrition survey in a longitudinal Chinese study in the COVID-19 era', Nutrients. Multidisciplinary Digital Publishing Institute, 12(11), p. 3269.

Zhang, J., Zhang, Y., et al. (2020) 'Emotional eating in pregnant women during the COVID-19 pandemic and its association with dietary intake and gestational weight gain', Nutrients. Multidisciplinary Digital Publishing Institute, 12(8), p. 2250.

Zhao, A. et al. (2020) 'Dietary diversity among Chinese residents during the COVID-19 outbreak and its associated factors', Nutrients. Multidisciplinary Digital Publishing Institute, 12(6), p. 1699. 